\title{
Marketplace as A Determination Factor for Customer Satisfaction
}

\author{
Febrianur Ibnu Fitroh Sukono Putra ${ }^{1}$, Diana Aqmala ${ }^{2}$, Aufa Marzuq Alwi ${ }^{3}$, Inggrit Faza Saputra ${ }^{4}$, Sisca Dian \\ Rahmawati $^{5}$ \\ 1,2,3 Management, Economics and Business Faculty, Semarang, Dian Nuswantoro University, Indonesia \\ ${ }^{4}$ Korea Business, Global Business Faculty, Busan, Youngsan University, South Korea \\ ${ }^{5}$ Management, Economics and Business Fakulty, Surakarta, Muhammadiyah Surakarta University, Indonesia
}

\begin{abstract}
The research aims to analyze the main factor determining Chinese Smartphone Customer Satisfaction. The population of this research were all customers who purchased Chinese smartphones in Surakarta, Semarang, Pemalang, Purworejo, Grobogan. The sampling technique used purposive sampling by taking 200 official store customers and 200 black-market customers. The data collection method was a survey by personal questionnaire with an data analysis used multiple linear regression and different tests (independent sample T-test). The results obtained several findings that the price perception, product quality, and marketplace significantly affect customer satisfaction. Finally, there are differences in customer satisfaction felt purchased Chinese smartphones in the official store with the black market.
\end{abstract}

Keywords - Chinese smartphone; Customer Satisfaction; Product Quality; Price Perception; and Marketplace.

\begin{abstract}
Abstrak
Penelitian ini bertujuan untuk menganalisis faktor utama yang menentukan Kepuasan Pelanggan Smartphone China. Populasi penelitian ini adalah seluruh konsumen yang membeli Smartphone China di Surakarta, Semarang, Pemalang, Purworejo, Grobogan. Teknik pengambilan sampel menggunakan purposive sampling dengan mengambil 200 pelanggan toko resmi dan 200 pelanggan black market. Metode pengumpulan data adalah survei dengan kuesioner pribadi dengan analisis data menggunakan regresi linier berganda dan uji beda (independent sample t-test). Hasil penelitian diperoleh beberapa temuan bahwa persepsi harga, kualitas produk, dan pasar berpengaruh signifikan terhadap kepuasan pelanggan. Terakhir, terdapat perbedaan kepuasan pelanggan yang dirasakan membeli Smartphone China di toko resmi dengan black market.
\end{abstract}

Kata kunci-Smartphone China; Kepuasan Pelanggan; Kualitas Produk; Persepsi Harga; Marketplace.

\section{INTRODUCTION}

Globalization has impacted all business sectors in whole countries of the world, especially at the international level. One of the significant factors pushing global business activity to develop rapidly is the local and international market share (Ball \& Shivakumar, 2005). Indonesia has predicate one of the biggest populated countries reaches more than 262 million people and it will increase by around 4 million (Badan Pusat Statistik, 2015). Indonesian entrepreneurs of all types of businesses competing to get market share as much as possible. The Indonesian customer's behaviour was consumptive make them be a lucrative market target. Most products demand by Indonesian people is sophisticated technology products, especially smartphones. A smartphone is a product that has basic computer capabilities and cannot compare to ordinary mobile phones. Companies that cannot innovate will knock out the technology business industry (Cummins et al., 2014). Smartphones have functioned as portable media players, low-end digital compact cameras, pocket video cameras, and GPS. Smartphones are also equipped with a high-resolution touch screen, a browser displaying full web-like on a PC, WiFi data access, and broadband internet (Ackaradejruangsri, 2013). Based on research conducted, people use a 
smartphone to support their daily activities because of ease to carry anywhere, sophisticated operational systems, fast start up / off, fast performance and comfortable to use, size proportional, and can be used in various places. Based on research conducted, people used smartphones to support their daily activities because it was easy to carry anywhere, sophisticated operational systems, fast start up/off, good performance and comfortable to use, proportional size, and usable in various places (Nielsen, 2011). The industry activities with high competition for smartphone distributors will threaten unable distributors because they have to face the amount taxes paid. Therefore, the unable distributor of smartphones must find a way to avoid taxes but still penetrate and make a profit in the smartphone market quickly, easily, and cheaply. Smartphones which distributed through the black market are very different from smartphones which spread at Official stores because smartphones distributed through the black market are essentially deliberately smuggled into the country to avoid the country's taxation system (Chaudhry et al., 2019).

Besides, the smartphones distributed at Official stores already have a legal license from the Directorate General of Post and Telecommunications of the Republic of Indonesia to be distributed to minimum standard markets set by the government (Amiruddin \& Azikin, 2008). The Chinese smartphones are currently dominated by several big brands such as Xiaomi, Oppo, Vivo, Honor, Huawei, Infinix, etc. But, the most dominant brand of the Chinese smartphone market in Indonesia is Xiaomi (Amalia \& Asmara, 2017). Based on these data and information, the companies are which Chinese smartphone distributors at official stores need to pay more attention and set the prioritize of marketing strategies related to price perceptions, marketplace, and product quality, so customers get a high level of satisfaction after purchased. This research aims to:

a. Analyzing the effect of price perception on consumer satisfaction who purchased Chinese smartphones.

b. Analyzing the effect of product quality on consumer satisfaction who purchased Chinese smartphones.

c. Analyze the level of satisfaction of consumers who purchased Chinese smartphones in the Black Market with consumers who purchased Chinese smartphones at the official store.

d. Analyze the difference in satisfaction of consumers who purchased Chinese smartphones in the Black Market with consumers who purchased Chinese smartphones at the official store.

\section{LITERATURE REVIEW}

Customer satisfaction is a feeling of pleasure or disappointment after comparing the actual performance product against the expected performance product, if the product performance is below expectations, the customer will not be satisfied. Then, if the product performance meets expectations, the customer will be satisfied, and if the product performance exceeds expectations, the customer will be very satisfied or happy (Kotler \& Keller, 2016). Another definition states if customer satisfaction is the difference between expectations and perceptions of actual performance or results. Customer satisfaction is the soul of company's sustain because it provides several benefits as the harmonious relationship between the company and their customers provide a good foundation for repurchase. Customer satisfaction will make them give recommendations to another customer potential through word of mouth to purchased their product too, encourage customer loyalty to the company or brand, build the company's reputation in the customer's perception, and increase its profits. Factors influencing customer satisfaction include product delivery systems, product or service performance, company/brand product/brand image (Tjiptono, 2015). Perception values about the price of a brand or company related to the value received by customers, employee performance, product performance, advantages and disadvantages of competitors (Putra et al., 2020).

Price perception is a feeling of spending an amount of money billed to get a product or service that customers purchased and benefit from the product or service purchased. Another definition according to (Paramananda \& Sukaatmadja, 2018) states that prices are monetary or non-monetary units that include certain utilities or uses that customers obtain to consume a product or service. Price becomes very important for customers because it will be a guideline to measure the compatibility between the benefits of the product received with the sacrifice given both in the form of money and others. The indicators for measure price perceptions variable for stimulating customer sensitivity to has purchase intention that includes price affordability, price competitiveness compared to another brand, and price compatibility with the benefits of features obtained customer (Suhendar \& Ruswanti, 2019). In a study conducted by Opusunju \& Ojeleye (2017) with the results is that price perception has a significant effect on customer satisfaction. Furthermore, another study conducted by Hustić \& Gregurec (2015) obtained the result that price perception has a positive effect on customer satisfaction. Research conducted by Fahrezzy \& Trenggana (2017) obtained the result that price 
perception positively affects customer satisfaction. Research conducted by Fahrezzy \& Trenggana (2017) also showed promising results, namely that price perception has a positive and significant effect on customer satisfaction. Price perception is a variable to evaluate the affordability of prices set by companies for the perceived perceptions of customers. Price perception is also one of the determining factors whether or not customers accept a product. The price perception is entirely the feeling that customers feel about the product after being purchased with various considerations that have been made. Therefore, the companies need to set the best prices until the customer has the perception "Their price is cheaper than the others", so the prices offered to market affordably and build customer satisfaction after purchase. Finally, if the price is set according to the product's performance, customers won't be disappointed with the brand alternative chosen.

Product quality is the ability of a product to carry out its functions, including reliability, durability, permanence, easily operation, product improvement, as well as other valuable attributes to meet the needs and expectations of customers when purchasing the product (Herawati et al., 2019). According to Kotler \& Keller (2016), product quality is the overall characteristics of a product and the ability to provide services to satisfy expressed or implied needs. Product quality reflects the capability of products to carry out their duties including durability, reliability, advancement, strength, ease of packaging, product separation, and other characteristics. The several dimensions reflect quality, including performance, appearance, features, reliability, conformance, durability, serviceability, aesthetic, and perceived quality (Saleem et al., 2015). Hoe \& Mansori (2018) with their research showed the results that product quality has a positive and significant effect on customer satisfaction. In another study conducted by Akkucuk \& Esmaeili (2016) states that product quality is a very significant influence on customer satisfaction. The results that show that product quality has a significant effect on customer satisfaction is also shown by research conducted by Brata, Husani, \& Ali (2017). The customers won't be interested in purchasing similar products because the chosen brands prioritize product quality and what customer needs, thereby increasing customer satisfaction expectations. The highest quality products with customer knowledge about product brands will provide confidence in measuring whether or not customers are satisfied. So it is not easy to produce products with the highest quality that have unique advantages compared to competitors. It leaves an impression on customers' minds so that it becomes the first choice when the customer repurchase in the future.

The official stores legally have an official certificate from the Directorate General of Post and Telecommunications of the Republic of Indonesia to distribute products, so it can say that official stores have to pay taxes following the provisions stipulated in the law that has been established. The official stores are also a designation for company organizations that have purchased goods directly from producers (makers) of goods intending to resell them. The profit from this type of retailer is the margin that the company has set to the distributor. Usually, the number of products distributed through stores is vast, so the official stores can redistribute them to lower retailers (retailers). The black market is a sector of economic activity involving illegal economic transactions, particularly the purchased and selling of merchandise whose goods are illegal. For example, stolen merchandise or official merchandise is intentionally sold illegally to avoid paying taxes (Kotler $\&$ Keller, 2016). The entry of smartphones into the territory of Indonesia is usually handled directly by official distributors. Smartphone distributors in Indonesia usually provide guarantees or guarantees for every product they distribute; the aim is to avoid and overcome all possibilities and risks that can reduce the function and value of the smartphone. It is different from the black market smartphone, which is a smartphone that is sold illegally where the goods are not entered through official channels or official distributors. Because it is not equipped with guarantees or guarantees that can transfer the risks that later the goods are problematic or production defects will harm the consumers themselves because there is no guarantee or guarantee. At first, the black market movement was closed, only a few people knew about the existence of the market, but slowly it seems that the black market can attract people's attention. It is rational if this event occurs, considering the human need for technology is increasingly limitless. Currently, consumers tend to care less about the origin of the goods, the authenticity of the goods, and even the quality of the goods, but only see the goods based on the prices, which tend to be cheap. This situation is because the black market goods enter an area without being taxed (Suhendar \& Ruswanti, 2019).

\section{RESEARCH METHODOLOGY}

The research type is quantitative by obtaining data which packaged in numbers and its analysis using statistics to meet scientific principles that are concrete/empirical, objective, measurable, rational, and systematic 
(Igwenagu, 2016). These independent variables are price perceptions, product quality, and marketplace, besides dependent variable is customer satisfaction. The sampling technique used purposive sampling with specific criteria that customers who purchased Chinese smartphones in Surakarta, Semarang, Pemalang, Purworejo, Grobogan. The samples were 200 respondents who purchased Chinese smartphones at the official store and 200 respondents who purchased Chinese smartphones in the black market. Data collection techniques using surveys and analyzed through validity and reliability tests. In the validity test, if $r$ tes $>r$ table so the item is valid, but if $\mathrm{r}$ test $<\mathrm{r}$ table so the item is invalid. In the reliability test, if the Cronbach alpha value is $>0.60$ so the questionnaire is reliable. The data analysis using multiple linear regression and Independent sample T-test.

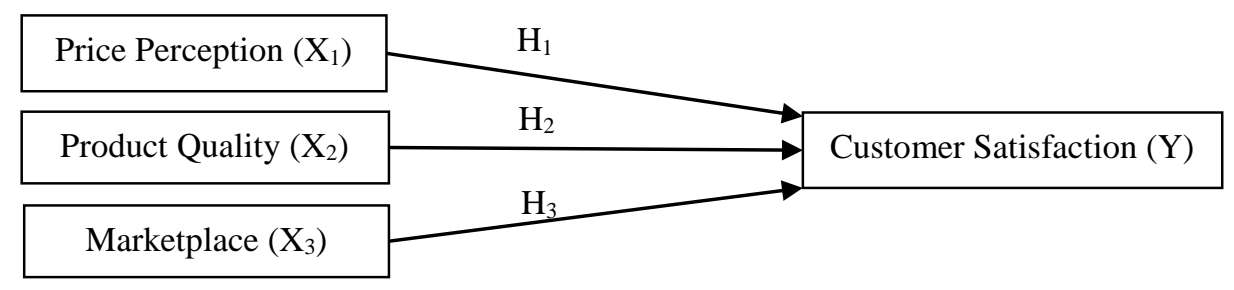

Figure 1. Theoretical Framework

\section{RESUlt AND DISCUSSION}

A. Result

The respondents in this research have several characteristics include gender, age, occupation, monthly income, and Chinese smartphone brands purchased at official stores or the black market.

Table 1. Data description

\begin{tabular}{|c|c|c|c|c|}
\hline \multirow{2}{*}{ No } & \multirow{2}{*}{ Variables } & & \multicolumn{2}{|c|}{ Marketplace } \\
\hline & & & Official Store & Black Market \\
\hline \multirow[t]{2}{*}{1} & Gender & Male & $126(31.5 \%)$ & $283(70,75 \%)$ \\
\hline & & Female & $274(68.5 \%)$ & $117(29,25 \%)$ \\
\hline \multirow[t]{4}{*}{2} & Age & $17-25$ years old & $267(66.75 \%)$ & $247(61.75 \%)$ \\
\hline & & 26 - 40 years old & $117(29.25 \%)$ & $126(31.5 \%)$ \\
\hline & & 41- 55 years old & $16(4 \%)$ & $27(6.75 \%)$ \\
\hline & & $>55$ years old & $0(0 \%)$ & $0(0 \%)$ \\
\hline \multirow[t]{4}{*}{3} & Occupation & State Civil Apparatus (PNS) & $110(27.5 \%)$ & $59(14.75 \%)$ \\
\hline & & Private Sector & $52(13 \%)$ & $146(36.5 \%)$ \\
\hline & & Entrepreneur & $47(11.75 \%)$ & $35(8.75 \%)$ \\
\hline & & Student & $191(47.75 \%)$ & $160(40 \%)$ \\
\hline \multirow[t]{4}{*}{4} & Monthly income & $<$ IDR 1.000 .000 & $74(18.5 \%)$ & $192(48 \%)$ \\
\hline & & IDR 1.000 .001 - IDR 3.000 .000 & $79(19.75 \%)$ & $187(46.75 \%)$ \\
\hline & & IDR 3.000.001 - IDR 5.000.000 & $127(31.75 \%)$ & $21(5.25 \%)$ \\
\hline & & $>$ IDR 5.000.000 & $120(30 \%)$ & $0(0 \%)$ \\
\hline \multirow[t]{6}{*}{5} & Chinese & Xiaomi & $182(45.5 \%)$ & $152(38 \%)$ \\
\hline & Smartphone & Vivo & $129(32.25 \%)$ & $43(10.75 \%)$ \\
\hline & brands purchased & Huawei & $15(3.75 \%)$ & $48(12 \%)$ \\
\hline & & Honor & $5(1.25 \%)$ & $25(6.25 \%)$ \\
\hline & & Meizu & $5(1.25 \%)$ & $10(2.5 \%)$ \\
\hline & & Oppo & $64(16 \%)$ & $122(30.5 \%)$ \\
\hline
\end{tabular}


The data description in table 1 shows that 200 respondents purchased at official stores, there were 126 male respondents $(31.5 \%)$ and 274 female respondents $(68.5 \%)$. Meanwhile, the 200 respondents purchased at the black market shows 283 male respondents (70.75\%) and 117 female respondents (29.25\%). Based on age, it shows that the 200 respondents who purchased at the official store is $17-25$ years were 267 people (66.75\%). In comparison, the black market shows the same results that most consumers are 17-25 years with 247 people $(61.75 \%)$. This result indicates that the behavior of young customers who have an age range of 17-25 years is more active in finding, purchasing, and evaluating Chinese smartphones purchased either at official stores or the black market. Based on occupation shows that 200 respondents who purchased at the official store have student status as many as 191 people $(47.75 \%)$. Meanwhile, the 200 respondents who purchased in the black market shows the most customers were students with 160 people (40\%). It can conclude that students have more time to conduct surveys, compare, purchased, and assess Chinese smartphones so that satisfaction is conveyed by student consumers more than other customers.

Based on monthly income shows that 200 respondents who purchased at official store, their behavior is different from one another. Most satisfied customers who purchased at official store have a monthly income of IDR 3.000.001 - IDR 5.000.000 as many as 127 people (31.75\%). In comparison, the other 200 respondents showed a difference behavior that customers with monthly income $<\mathrm{Rp} 1,000,000$ were more satisfied purchasing in the black market with 192 people (48\%). There are differences in customer behavior to purchasing Chinese smartphones at official store or black market. This result shows that if a customer's monthly income is IDR 3.000.001 - IDR 5.000.000, they will be more satisfied purchasing at official store, while customers with monthly income of < IDR 1,000,000 are more satisfied purchasing in the black market. The 200 respondents who purchased at the official store chose different brands when Xiaomi is the most brand that satisfies customers with 182 people (45.5\%), Vivo with 129 people (31.25\%), Oppo with 64 people (16\%), Huawei 15 people $(3.75 \%)$, Honor and Meizu each with 5 people $(1.25 \%)$. Besides, customers in the black market purchased Xiaomi as many as 152 people (38\%), Oppo with 122 people (30.5\%), Huawei with 48 people (12\%), Vivo with 43 people (10.75\%), Honor with 25 people (6.25\%), and Meizu with 10 people (2.5\%). The significant difference between Chinese smartphone brands in official store and black market shows that customers are more evenly distributed in purchasing Chinese smartphones at black market than official store. This result is because customers feel that the products in black market have more alternative price and quality. While in the official store, customers prefer to purchase Xiaomi and Oppo brands because relate to price, product quality, service, and brand trust.

A validity test uses to measure whether a questionnaire is valid or not. A questionnaire is said to be valid if the questions on the questionnaire can reveal something that the questionnaire will measure. If $r$ test $>r$ table so the item is declared valid.

Table 2. Validity Test

\begin{tabular}{|c|c|c|c|c|c|}
\hline \multirow[b]{2}{*}{ No } & \multirow[b]{2}{*}{ Variable } & \multicolumn{2}{|c|}{ Marketplace } & \multirow[b]{2}{*}{ r-table } & \multirow[b]{2}{*}{ Result } \\
\hline & & $\begin{array}{c}\text { Official Store } \\
\left(\mathbf{r}_{\text {test }}\right)\end{array}$ & $\begin{array}{c}\text { Black Market } \\
\left(\mathbf{r}_{\text {test }}\right)\end{array}$ & & \\
\hline \multirow{4}{*}{1} & \multirow{4}{*}{ Price Perception } & 0,799 & 0,643 & \multirow{4}{*}{0,138} & \multirow{4}{*}{ Valid } \\
\hline & & 0,725 & 0,584 & & \\
\hline & & 0,722 & 0,805 & & \\
\hline & & 0,794 & 0,707 & & \\
\hline \multirow{4}{*}{2} & \multirow{4}{*}{ Product Quality } & 0,736 & 0,826 & \multirow{4}{*}{0,138} & \multirow{4}{*}{ Valid } \\
\hline & & 0,772 & 0,851 & & \\
\hline & & 0,802 & 0,859 & & \\
\hline & & 0,837 & 0,805 & & \\
\hline \multirow{5}{*}{3} & \multirow{5}{*}{ Customer Satisfaction } & 0,625 & 0,800 & \multirow{5}{*}{0,138} & \multirow{5}{*}{ Valid } \\
\hline & & 0,734 & 0,879 & & \\
\hline & & 0,753 & 0,887 & & \\
\hline & & 0,745 & 0,918 & & \\
\hline & & 0,753 & 0,908 & & \\
\hline
\end{tabular}


The validity test results of price perception, product quality, and customer satisfaction indicate that all statement items on the questionnaire are valid because $r_{\text {test }}>r_{\text {table }}(0.138)$. The reliability test uses to a measurement tool in measuring a particular event with the condition that the Cronbach Alpha value is $>0.6$ so the measuring instrument will show consistent results when used in future research.

Table 3. Reliability Test

\begin{tabular}{ccccc}
\hline No & Variable & \multicolumn{2}{c}{ Marketplace } & Result \\
\cline { 3 - 4 } & Price Perception & $\begin{array}{c}\text { Official Store } \\
\text { (Cronbach Alpha) }\end{array}$ & $\begin{array}{c}\text { Black Market } \\
\text { (Cronbach Alpha) }\end{array}$ & \\
\hline 1 & Product Quality & 0,799 & 0,643 & Reliable \\
2 & 0,736 & 0,826 & Reliable \\
3 & Customer Satisfaction & 0,625 & 0,800 & Reliable \\
\hline
\end{tabular}

The reliability test results above show that all variables have a Cronbach Alfa coefficient $>0.6$, so all items are reliable. Therefore, the measuring instrument used on the variables of price perception, product quality, and consumer satisfaction will show consistent results when used in future research.

Table 4. Multiple Linear Regression Test Results

\begin{tabular}{lcrrr}
\hline \multicolumn{1}{c}{ Variabel } & Coefficient Beta & Beta & \multicolumn{1}{c}{$\mathrm{t}_{\text {count }}$} & \multicolumn{1}{c}{$p$} \\
\hline (Constant) & 2,466 & & 2,061 & 0,040 \\
Price Perception & 0,204 & 0,091 & 2,755 & 0,006 \\
Quality Product & 0,765 & 0,600 & 14,529 & 0,000 \\
Marketplace & 2,110 & 0,219 & 5,363 & 0,000 \\
\hline $\mathrm{R}^{2} \quad=0,591$ & & & & \\
$\mathrm{~F}_{\text {count }} \quad=190,534$ (Sig. 0,000) & & & & \\
\hline
\end{tabular}

The results showed that the t-test obtained perception of price, product quality, and marketplace have significant influence on customer satisfaction. The beta value of the variable marketplace (X3) shows the level of customers satisfaction who purchased Chinese smartphones at official stores by $21.9 \%$ higher than the black market. The accuracy of the model test results shows that the perception of price, product quality, and marketplace are an appropriate and acceptable model to explain variations of customer satisfaction variables with sig value. $0,000<0.05$. Variable perception of price, product quality, and marketplace can explain the variation of the customer satisfaction variable by $59.1 \%$.

Table 5. Independent sample t-test

\begin{tabular}{lrrrr}
\hline \multicolumn{1}{c}{ Variabel } & \multicolumn{1}{c}{$\mathrm{F}_{\text {count }}$} & \multicolumn{1}{c}{ Sig. } & \multicolumn{1}{c}{$\mathrm{t}_{\text {count }}$} & \multicolumn{2}{c}{ Sig. (2-tailed) } \\
\hline Price Perception $\left(\mathrm{X}_{1}\right)$ & 5,005 & 0,026 & $-0,578$ & 0,563 \\
Quality Product $\left(\mathrm{X}_{2}\right)$ & 25,466 & 0,000 & 14,979 & 0,000 \\
Customer Satisfaction $(\mathrm{Y})$ & 55,504 & 0,000 & 14,065 & 0,000 \\
\hline
\end{tabular}

Based on the results of different tests of price perception variables, it can conclude the value of sig. (2-tailed) is $0.563>0.05$ so there is no difference in price perception between customers who purchased Chinese smartphones at official stores and the black market. From customers' perception, prices offered by Chinese smartphone companies are both cheap and more affordable than the prices of smartphones from other brands. Then, the different tests of product quality variables showed the value of sig. (2-tailed) is $0,000<0.05$ so there are differences in product quality between official stores and black market, it's due to customers' received perceptions of the products quality when purchased Chinese smartphones in official stores produce different qualities than the black market ranging from features to performance provided. The different tests of customer satisfaction who purchased Chinese smartphones in official stores with customers who purchased Chinese smartphones in the black market showed the value of sig. (2-tailed) of $0,000<0.05$, it can conclude there is a different satisfaction felt by customers when purchased Chinese smartphones at official stores than black market. 


\section{B. Discussion}

The test results showed the price perception has a significant effect on customer satisfaction (Supported). This result supports the research conducted by Opusunju \& Ojeleye (2017), Hustić \& Gregurec (2015), and Trenggana (2018) which states that price perception has positive and significant effect on customer satisfaction. This research also explains that the price perception of customers who purchased Chinese smartphones both in official stores and the black market has a significant effect on satisfaction obtained. Because, when customer purchased a Chinese smartphone which has good performance with relatively cheaper price than other smartphone brands. The purchase price of Chinese smartphones by the performance as good and promised could create maximum customer satisfaction. Even in the future, they won't hesitate to recommend that marketplace to friends or relatives to purchased Chinese smartphones (Victor et al., 2018). The increased customer's price perception of products offered by the company regarding affordability of prices, suitability of price with the smartphone performance, and price competitiveness compared to others will also increase customer satisfaction. Assessment of customers' perceptions of one another over price varies depending on their characteristics and background. Finally, the customer's evaluation of the price of Chinese smartphones has different both purchased at official stores or black market.

Based on the result, product quality has a significant effect on customer satisfaction (supported). This result supports the research conducted by Sitanggang, Sinulingga, \& Fachruddin (2019), Akkucuk and Esmaelli (2016), and Hasniaty (2015) which states that product quality has positive and significant effect on customer satisfaction. A high level of product quality will create high customer satisfaction as well. Because customers will definitely like products that offer the best quality, the best performance with attractive features. When customers purchase a product, they will compare one product to another and pay more attention to products that provide more benefits because the customers want to meet their needs and satisfy their desires. Therefore, smartphone companies must have the best quality product and affordable prices, so customers will purchase the company's products. Product quality is an essential advantage that the company must own because there is a different perception between customers and them. The increase in Chinese smartphone products' ability to meet the customer needs and satisfy the desire will increase customer satisfaction. So in the future, the satisfied customers will surely repurchase the Chinese smartphones in that marketplace and recommend them to their friends and relatives as potential new customers.

This research is in line with that conducted by Verry \& Winarno (2019) which states that the marketplace has a positive and significant effect on customer satisfaction. Customer satisfaction is a feeling of pleasure or disappointment someone who appears after comparing the product performance thought about the expected performance. If the performance is below expectations, the customer is not satisfied; If performance meets expectations, the customer is satisfied; If performance exceeds expectations, the customer is very satisfied or happy (Kotler, 2016). Customer satisfaction is a soul because it provides several benefits such as a reasonable basis for repurchases, forms recommendations by word of mouth that benefit the company, encourages the creation of loyal customers, and builds a company's reputation in the eyes of customers and can undoubtedly increase profits. Satisfaction will positively impact the form of a desire to purchase the same product one day when the same needs reappear. When the customer makes a decision, there are expectations about the performance that will result from the product, including the product has better benefits than expected by the customer, the product has benefits as expected by the customer, or the product has worse benefits expected.

The alternative can make companies' efforts to provide customer satisfaction by providing complete information about product features and quality, user interface quality, service information quality, ease of purchasing processes, participation in e-commerce, perceptions about security, and attraction of stores. The perception of price is entirely the feeling that customers feel about the product that has been consumed, with various considerations that have been made, so that when making a purchasing decision, customers get maximum satisfaction. The official store needs to compare their product price with competitors, so in customers' perceptions, the Chinese smartphone price is not too high and still affordable and can cause a sense of satisfaction to customers such as purchased in competitors especially the black market. Besides, if the price is following product performance and supported by pampering services, customers will not be disappointed with the official store as a marketplace for purchased Chinese smartphones. Customers will not desire to purchase a Chinese smartphone to another marketplace with similar products if the official store prioritizes the provision of the highest quality products, thus impacting the growth of satisfaction in the minds of customers. Chinese smartphone products that are offered with the best quality supported by comprehensive customer knowledge will provide confidence in determining whether or not customers are satisfied with a marketplace for purchasing 
Chinese smartphones. Besides, customer satisfaction with official stores will exceed the black market if the marketplace's capabilities facilitate customers in obtaining product information, product durability, product reliability, ease of operation and improvement, and other valuable attributes.

The difference in customer satisfaction between official stores and the black market is that customers at the official store can directly obtain product information and confirm the promised features, product performance, product service to customer expectations, and security with good service. Besides, differences in price perceptions make the level of customer satisfaction also experience differences, this is because price is one of the variables that are quite sensitive for customers. Suppose customers who purchased a Chinese smartphone in the black market can be said to be satisfied. In that case, it's just that it depends on the price of the Chinese smartphone which is cheaper than official stores so that it fosters satisfaction for customers being able to obtain products at low prices, but the level of safety and quality of the products received is less guaranteed, distributor service that is difficult to guess. It takes a long time for the smartphone to reach home first to confirm its quality.

The results of this research can contribute to the knowledge development of marketing management related to developing customer satisfaction of Chinese smartphone official stores. This result can also be a reference for future research on the number of customer loyalty comparisons of Chinese smartphone users between the official store and the black market. For the management of the official store, a unique marketing strategy that is impossible for competitors to imitate in the black market is the perception that the price of Chinese smartphones in the official store is also cheap with better product and service quality compared to the black market. Official stores can also create websites or social media to increase customer satisfaction compared to the black market and improve competitiveness, brand image, and market share. This research can be study materials for the government or stakeholders who can support the Chinese smartphone market price which remains stable and increases the competitiveness of the official stores. The government and stakeholders can also publish some policies for black market Chinese smartphone distributors to get taxes so they don't damage the market ecosystem.

\section{CONCLUSION AND SUGGESTIONS}

\section{A. Conclusions}

Based on the analysis of customer satisfaction behaviour who purchased Chinese smartphones, it can draw several conclusions: price perception, product quality, and marketplace have positively and significantly affected the customer satisfaction who purchased Chinese smartphones. The results of this research also show there are differences in the level of customer satisfaction who purchased Chinese smartphones at official stores and customers who purchased Chinese smartphones in the black market. This difference is supported by customers' higher level of satisfaction when purchased Chinese smartphones at official stores. This result is because for customers when purchased Chinese smartphone directly, there is no need to wait a long time to obtain and confirm the features, performance, product capabilities, and security of the smartphone purchased. Furthermore, the $\mathrm{F}$ test found that the model used in the research was feasible and appropriate to measure the customer satisfaction who purchased Chinese smartphones. Variable price perception, product quality, and marketplace can explain the variation of the customer satisfaction variable by $59.1 \%$.

\section{B. Limitations}

There are some limitations of this research, including:

1. Many factors affect consumer satisfaction, but researchers only use a few variables, namely price perception, product quality, and marketplace.

2. On the data description, the researchers did not add detailed information about the monthly outcome.

3. Researchers only use several indicators to measure research variables from one expert but do not add indicators sourced from other experts.

\section{Recommendations}

We recommend that in future research also use other variables to create greater coefficient of determination and be able to explain variations of customer satisfaction comprehensively. Future research are suggested to use a smartphone provider company as an object of research, to be able to compare the strategies used with the level of satisfaction obtained by customers. 


\section{Acknoledgement}

The author thanks all participants involved for helping to compile, provide various data and information so that this research can be completed.

\section{REFERENCES}

Ackaradejruangsri, P. (2013). The Effect of Product Quality Attributes on Thai Consumers Purchased Decisions. Ritsumeikan Journal of Asia Pacific Studies, 33, 14-24.

Akkucuk, U., \& Esmaeili, J. (2016). The Impact of Brands on Consumer Purchased Behavior: An Empirical Study on Smartphone Purchaseders. Journal of Research in Business \& Social Science, 5(4), 1-16. https://doi.org/10.20525/ijrbs.v5i4.551

Amalia, S., \& Asmara, M. O. (2017). Pengaruh Citra Merek, Harga, dan Kualitas Produk terhadap Keputusan Pembelian Handphone Merek Xiaomi di Kota Langsa. Jurnal Manajemen Dan Keuangan, 6(1), 666. www.wikipedia.org

Amiruddin, \& Azikin, Z. (2008). Pengantar Metodologi Penelitian Hukum Teknologi Informasi. PT Raja Grafindo Persada.

Badan Pusat Statistik. (2015). Survei Penduduk Antar Sensus (SUPAS) 2015.

Ball, R., \& Shivakumar, L. (2005). Earnings Quality in UK Private Firms: Comparative Loss Recognition Timeliness. Journal of Accounting and Economics, 39(1), 83-128. https://doi.org/10.1016/j.jacceco.2004.04.001

Brata, B. H., Husani, S., \& Ali, H. (2017). The Influence of Quality Products, Price, Promotion, and Location to Product Purchase Decision on Nitchi At PT. Jaya Swarasa Agung in Central. Saudi Journal of Business and Management Studies, 2(4B), 433-445. https://doi.org/10.21276/sjbms

Chaudhry, A. F., Hanif, M. M., Hassan, S., \& Chani, M. I. (2019). Efficiency of The Black Foreign Exchange Market. International Journal of Economics and Finance, 11(2), 165. https://doi.org/10.5539/ijef.v11n2p165

Cummins, S., Peltier, J. W., Schibrowsky, J. A., \& Nill, A. (2014). Consumer Behavior in The Online Context. Journal of Research in Interactive Marketing, 8(3), 169-202. https://doi.org/10.1108/JRIM-04-2013-0019

Fahrezzy, R. S., \& Trenggana, A. F. M. (2017). Pengaruh Kualitas Produk dan harga terhadap keputusan pembelian konsumen laptop Asus. Jurnal Indonesia Membangun, 2(2), 142-150.

Hasniaty. (2015). Customer Perception On Products Pricing Service Quality Towards Customers Quality Relationships And Loyalty Of Domestic Airlines Indonesia. International Journal of Scientific \& Technology Research, 4(8), 181-188.

Herawati, Prajanti, S. D. W., \& Kardoyo. (2019). Predicted Purchasing Decisions from Lifestyle, Product Quality, and Price through Purchase Motivation. Journal of Economic Education, 8(1), 1-11. http://journal.unnes.ac.id/sju/index.php/jeec

Hoe, L. C., \& Mansori, S. (2018). The Effects of Product Quality on Customer Satisfaction and Loyalty: Evidence from Malaysian Engineering Industry. International Journal of Industrial Marketing, 3(1), 20. https://doi.org/10.5296/ijim.v3i1.13959

Hustić, I., \& Gregurec, I. (2015). The Influence of Price on Customer's Purchase Decision. Central European Conference on Information and Intelligent Systems, http://www.ceciis.foi.hr/app/public/conferences/1/ceciis2015/papers/754.pdf

Igwenagu, C. (2016). Fundamentals of Research Methodology and Data Collection. LAP Lambert Academic Publishing.

https://www.researchgate.net/publication/303381524_Fundamentals_of_research_methodology_and_data _collection

Kotler, P., \& Keller, K. L. (2016). Marketing Management (15th ed.). Pearson Education.

Opusunju, M. I., \& Ojeleye, Y. C. (2017). Current Price and It Effects on Consumer Purchase Decision in Ikot 
Ekpene Main Market, Akwa Ibom State. International Journal of Economics and Socio-Legal Sciences, 2(6), 1-13.

Paramananda, N., \& Sukaatmadja, I. P. G. (2018). The Impact of Price Perception And Brand Image on Customer Satisfaction and Repurchase Intention. International Journal of Economics, Commerce and Management, 12(2), 59-73. https://doi.org/10.5937/poseko14-15894

Putra, F. I. F. S., Wiyadi, \& Saputro, P. E. (2020). Analisis Komparasi Kepuasan Konsumen yang Membeli Smartphone China Pada Gerai Resmi dan Black Market. Jurnal Manajemen Daya Saing, 21(2), $79-87$.

Saleem, B. A., Ghafar, A., Ibrahim, M., Yousuf, M., \& Ahmed, N. (2015). Product Perceived Quality and Purchase Intention with Consumer Satisfaction. Global Journal of Management and Business Research: E Marketing, 15(1), p21-28. https://globaljournals.org/GJMBR_Volume15/3-Product-Perceived-Quality.pdf Sitanggang, J. M., Sinulingga, S., \& Fachruddin, K. A. (2019). Analysis Of The Effect Of Product Quality On Customer Relationship Management Of Indihome ATPT Telkom Regional 1 Sumatera, Medan, North Sumatra, Indonesia. American International Journal of Business Management (AIJBM, 2(3), 26-37.

Suhendar, U., \& Ruswanti, E. (2019). Effect of Product Quality , Perception of Price and Satisfaction To Customer Loyalty ( Study on Agroindustrial Company in Indonesia ). International Journal of Economics, Commerce and Management, VII(3), 23-33.

Tjiptono, F. (2015). Strategic Marketing. Andi Offset.

Verry, \& Winarno, W. W. (2019). Analysis of Indonesian Marketplace Based on Customer Satisfaction, Trust and Loyalty. International Journal of Engineering Research and Advanced Technology, 05(02), 01-12. https://doi.org/10.31695/ijerat.2019.3371

Victor, V., Thoppan, J. J., Nathan, R. J., \& Maria, F. F. (2018). Factors Influencing Consumer Behavior and Prospective Purchase Decisions in a Dynamic Pricing Environment-An Exploratory Factor Analysis Approach. Journal of Social Sciences, 7(9), 1-14. https://doi.org/10.3390/socsci7090153 